\title{
Information Literacy Skills of Undergraduates of University of Moratuwa
}

\section{T. M. Seneviratne ${ }^{\text {b }}$}

B Sc. (Kelaniya), P G. Dip. in Env. Mgmt. (Moratuwa), M LS (Colombo)

\section{V.M. Wickramasinghe ${ }^{\mathrm{c}}$}

B. Sc. Bus. Adm. (USJ), M. A. Labor Studies (Colombo), Ph. D. (Manchester-UK)

\begin{abstract}
Information literacy has been recognized as one of the core literacies of the 21st century. An information literate person is capable of identifying, locating, evaluating, organizing, and effectively using the information to address and help resolve personal, job related, or broader social issues and problems. This research was conducted to investigate the status of information literacy skills of the undergraduates of University of Moratuwa. Surveyed a stratified random sample of 918 undergraduates. The findings and implications of the research have been discussed
\end{abstract}

Keywords: $\quad$ Information Literacy, Information Skills, Library Instruction

\section{Introduction and objectives}

Information literacy is "a set of abilities requiring individuals to recognize when information is needed and have the ability to define, locate, evaluate and use effectively the needed information" (Association of College and Research Libraries, 2000). Hence, people are considered to be information literate when they are able to identify, locate, evaluate, organize, and effectively use information to address and help resolve personal, job related, or broader social issues and problems (Catts, 2005; Catts and Lau, 2008). American Library Association Presidential Committee on information literacy says "ultimately, information literate people are those who have learned how to learn. They know how to learn because they know how knowledge is organised, how to find information and how to use information in such a way

\footnotetext{
${ }^{\mathrm{b}}$ Senior Assistant Librarian, University of Moratuwa E-mail: thushari@lib.mrt.ac.lk ' Senior Lecturer, Department of Management of Technology, Faculty of Engineering, University of Moratuwa. E-mail: vathsala@mot.mrt.ac.lk
} 
that others can learn from them. They are people prepared for lifelong learning, because they can always find information needed for any task or decision at hand" (American Library Association, 1989). Hence, information literacy is the foundation for lifelong learning. "It is common to all disciplines, to all learning environments, and to all levels of education. It enables learners to master content and extend their investigations, become self-directed, and to assume greater control over their own learning" (Association of College and Research Libraries, 2000).

When undergraduates passing out from universities are seen as tomorrow's workers, all undergraduates have to be information literate and such people become valuable assets to any employer. At present, undergraduates simply cannot cope with the huge amounts of information available. On the other hand, undergraduates are faced with different styles of learning and assimilating. Information literate undergraduates will have the skills in finding information for any purpose. Information literacy education and training have become vital in this environment.

University libraries offer education and training on information literacy to undergraduates without assessing their information literacy skill levels at the commencement of degree programmes. If the initial level of information literacy skills of newly entered undergraduates were known, education and training could be designed to overcome student weaknesses (Thirion and Pochet, 2009). Therefore, there is a need to evaluate information literacy skills of undergraduates in designing library instructional programmes. Information literacy skills are usually assessed using three distinct methodologies: self-evaluation that allows the assessment of skills at a particular point of time; third-party evaluation that allows the assessment of an individual's learning/acquisition of skills; and peer evaluation that allows the evaluation of the possession of skills as perceived by peers (Camuffo and Gerli 2004; Graham and Tarbell 2006; Marsh, 1984).

Although few attempts have been made in Sri Lanka to identify information literacy of undergraduates (e.g. Jayatissa, 2009), no study has been undertaken, to date, to investigate information literacy of undergraduates 
based on a proper framework with a university-wide coverage. Therefore, the objective of this study is to assess information literacy skills of undergraduates using a test.

\section{Methodology}

Information literacy skills were assessed using third-party evaluation (by the two authors) methods proposed in literature.

\subsection{Measures}

\section{a) Information literacy skills based on MCQ test items}

The information literacy skills of undergraduates were assessed using 25 multiple choice questions (MCQs) developed for the study. In doing so, four information literacy competency standards for higher education developed by Association of College and Research Libraries, USA (ACRL, 2000) were adopted. Eight information literacy skills for these standards were adopted from Project SAILS (2009). A matrix of skills and standards corresponding to these $25 \mathrm{MCQs}$ are shown in Table 1.

Table 1- Matrix of skills and standards: $M C Q$ items

\begin{tabular}{|c|c|c|c|c|}
\hline $\begin{array}{l}\text { ACRL } \\
\text { Standard }\end{array}$ & $\begin{array}{l}\text { Determine } \\
\text { the nature } \\
\text { and extent } \\
\text { of } \\
\text { information } \\
\text { needed }\end{array}$ & $\begin{array}{c}\text { Access } \\
\text { required } \\
\text { information } \\
\text { effectively } \\
\text { and } \\
\text { efficiently }\end{array}$ & $\begin{array}{l}\text { Evaluate } \\
\text { information } \\
\text { and its } \\
\text { sources }\end{array}$ & $\begin{array}{l}\text { Understand } \\
\text { many of the } \\
\text { economic, } \\
\text { legal and } \\
\text { social issues }\end{array}$ \\
\hline Developing a research strategy (Skill1) & 1,3 & 2 & - & - \\
\hline Selecting and finding tools (Skill2) & 5 & 4,6 & 7 & - \\
\hline Searching (Skill3) & - & $8,9,25$ & - & - \\
\hline Using finding tool features (Skill4) & - & $10,11,12$ & - & - \\
\hline Retrieving sources (Skill5) & - & $13,14,15$ & - & - \\
\hline Evaluating sources (Skill6) & - & - & $16,17,18$ & - \\
\hline Documenting sources (Skill7) & - & 19 & - & 20,21 \\
\hline $\begin{array}{l}\text { Understanding of economic, legal and social } \\
\text { issues (Skill8) }\end{array}$ & - & - & - & $22,23,24$ \\
\hline
\end{tabular}


As shown in Table 1, Skill1 assesses the ability in defining and articulating the need for information. Skill2 assesses the ability in identifying variety of types and formats of potential information sources, and costs and benefits of acquiring the needed information. Skill3 assesses the ability in accessing the needed information effectively and efficiently using different search strategies. Skill4 assesses the knowledge on characteristics and features of different information sources. Skill5 assesses the ways and means of retrieving information online or in person using variety of methods according to the characteristics and features of information sources. Skill6 assesses ability of evaluating information and its sources, and incorporating selected information into his/her knowledge base and value system. Skill7 assesses knowledge and experience on acknowledging information sources using appropriate documentation style. Skill8 assesses economic, legal and social issues surrounding the use of information.

\section{b) Demographic Characteristics}

Demographic characteristics, namely, $Z$ Score in the $A / L$ examination and district, age, gender, ethnicity, religion and some socio-economic details relevant to scope of study such as mother's employment, influence of relatives (grandparents etc.) living with them investigated.

\subsection{Method of sample selection}

A random sample of level 1 undergraduates representing Faculties of Architecture, Engineering, and Information Technology (Batch 08) were selected. To assess information literacy skills across academic years, random samples of Level 2 (Batch 07) and Level 4 undergraduates (Batch 05) representing Faculty of Engineering were also selected.

\subsection{Method of data collection}

Data was collected from March 2009 to April 2009. The majority of students responded to the questionnaire in a classroom setting.

\subsection{Method of data analysis}

Data was analyzed using "Statistical Package for Social Sciences" (SPSS Inc. Chicago, IL, USA). In assessing 25 MCQs, each correct answer was given 1.0 
mark, partly-correct answer was given 0.5 , and wrong answer was given 0.0 (zero). The marks obtained for each MCQ was averaged to arrive at a mean score for each skill and an overall mean score for overall information literacy skills.

\section{Results:}

\subsection{Response rate}

Table 2 shows the details of population and sample of the study. 918 valid responses were received at a overall representation rate of $38 \%$.

Table 2- Population and sample

\begin{tabular}{l|c|c|c}
\hline Batch, Level and Faculty & Population & $\begin{array}{c}\text { Sample (Responses } \\
\text { received) }\end{array}$ & $\begin{array}{c}\% \\
\text { Represented }\end{array}$ \\
\hline $\begin{array}{l}\text { 08 Level 1 Faculty of } \\
\text { Architecture (Arch. L1) }\end{array}$ & 291 & 122 & 42 \\
$\begin{array}{l}\text { 08 Level 1 Faculty of } \\
\text { Information Technology (IT L1) }\end{array}$ & 98 & 39 & 40 \\
08 Level 1 Faculty of \\
$\begin{array}{l}\text { Engineering (Eng. L1)* } \\
\text { 07 Level 2 Faculty of } \\
\begin{array}{l}\text { Engineering (Eng. L2)* } \\
\text { 05 Level 4 Faculty of } \\
\text { Engineering (Eng. L4) }\end{array}\end{array}$ & 706 & 409 & 22 \\
& 588 & 159 & 32 \\
\hline
\end{tabular}

Note: * Includes B.Sc. in Transport \& Logistics Management. Does not include B. Design in Fashion Design \& Product Development.

${ }^{\dagger}$ Does not include B.Sc. in Transport \& Logistics Management and B. Design in Fashion Design \& Product Development.

\subsection{Respondents' demographic characteristics}

Respondents' demographic characteristics are described in terms of their Z Score in the A/L examination, age, gender, ethnicity, religion and some socioeconomic details in Table 3. 
Table 3 - Characteristics of the respondents

\begin{tabular}{|c|c|c|c|c|c|}
\hline & \multicolumn{5}{|c|}{ Faculty } \\
\hline & \multirow{2}{*}{$\begin{array}{c}\text { Arch. } \\
\text { L } 1 \\
(n=122)\end{array}$} & \multirow{2}{*}{$\begin{array}{c}\text { IT } \\
\text { L } 1 \\
(n=39)\end{array}$} & \multicolumn{3}{|c|}{ Eng. } \\
\hline & & & $\begin{array}{c}\mathrm{L} 1 \\
(\mathrm{n}=409)\end{array}$ & $\begin{array}{c}\text { L2 } \\
(n=159)\end{array}$ & $\begin{array}{c}\mathrm{L} 4 \\
(\mathrm{n}=189)\end{array}$ \\
\hline \multicolumn{6}{|l|}{$\begin{array}{l}\mathrm{Z} \text { Score in the } \mathrm{A} / \mathrm{L} \\
\text { examination: }\end{array}$} \\
\hline Mean & 2.5 & 1.6 & 2.2 & 2.1 & 2.2 \\
\hline Std. Deviation & 0.9 & 0.3 & 0.4 & 0.4 & 0.36 \\
\hline \multicolumn{6}{|l|}{ Age: } \\
\hline Mean & 20.75 & 21.29 & 20.92 & 21.90 & 23.80 \\
\hline Std. Deviation & 0.72 & 0.76 & 1.24 & 0.76 & 0.68 \\
\hline \multicolumn{6}{|l|}{ Gender (\%): } \\
\hline Male & 45.8 & 62.9 & 71.7 & 76.4 & 84.0 \\
\hline Female & 54.2 & 37.1 & 28.3 & 23.6 & 16.0 \\
\hline \multicolumn{6}{|l|}{ Ethnicity (\%): } \\
\hline Sinhala & 89.0 & 85.3 & 90.1 & 91.8 & 77.6 \\
\hline Tamil & 9.3 & 11.8 & 7.3 & 6.2 & 16.1 \\
\hline Muslim/Moor & 0.8 & 2.9 & 2.6 & 2.1 & 5.2 \\
\hline Other & 0.8 & - & - & - & 1.1 \\
\hline \multicolumn{6}{|l|}{ Religion (\%): } \\
\hline Buddhist & 83.1 & 85.3 & 83.1 & 82.3 & 69.9 \\
\hline Hinduism & 6.8 & 11.8 & 6.5 & 4.8 & 14.5 \\
\hline Christian & 9.3 & - & 7.5 & 10.2 & 9.2 \\
\hline Islam & 0.8 & 2.9 & 2.3 & 2.0 & 5.8 \\
\hline Other & - & - & 0.5 & 0.7 & 0.6 \\
\hline \multicolumn{6}{|l|}{$\begin{array}{l}\text { Influence of grandparents } \\
\text { or any other relatives } \\
\text { living }(\%) \text { : }\end{array}$} \\
\hline No & 53.0 & 51.4 & 48.1 & 53.8 & 52.3 \\
\hline Yes & 47.0 & 48.6 & 51.9 & 46.2 & 47.7 \\
\hline \multicolumn{6}{|l|}{$\begin{array}{l}\text { Mother in a paid } \\
\text { employment/housewife } \\
(\%) \text { : }\end{array}$} \\
\hline Housewife & 65.8 & 60.0 & 55.4 & 51.0 & 59.6 \\
\hline $\begin{array}{l}\text { In paid } \\
\text { employment }\end{array}$ & 34.2 & 40.0 & 44.6 & 49.0 & 40.4 \\
\hline
\end{tabular}

Table 4 shows administrative provinces from which undergraduates represented in the sample entered the university. 
Table 4 - Provinces- undergraduates represented in the sample entered the university (\%)

\begin{tabular}{lccccc}
\hline \multirow{2}{*}{ Province } & \multicolumn{5}{c}{ Faculty } \\
\cline { 2 - 6 } & Arch. & IT & \multicolumn{3}{c}{ Eng. } \\
\cline { 2 - 6 } & $\begin{array}{c}\mathrm{L} \text { 1 } \\
(\mathrm{n}=122)\end{array}$ & $\begin{array}{c}\mathrm{L} 1 \\
(\mathrm{n}=39)\end{array}$ & $\begin{array}{c}\text { L1 } \\
(\mathrm{n}=409)\end{array}$ & $\begin{array}{c}\text { L2 } \\
(\mathrm{n}=159)\end{array}$ & $\begin{array}{c}\text { L4 } \\
(\mathrm{n}=189)\end{array}$ \\
\hline Western & 32 & 37 & 61 & 54 & 61 \\
Central & 18 & 9 & 2 & 8 & 5 \\
Southern & 13 & 12 & 16 & 16 & 15 \\
North Western & 10 & 9 & 8 & 7 & 5 \\
Sabaragamuwa & 8 & 12 & 3 & 5 & 2 \\
North Central & 5 & 6 & 3 & 1 & 2 \\
Uva & 5 & 9 & 1 & 3 & 1 \\
Eastern & 5 & 3 & 1 & 1 & 2 \\
Northern & 4 & 3 & 5 & 5 & 7 \\
\hline & 100 & 100 & 100 & 100 & 100 \\
\hline
\end{tabular}

\subsection{Information literacy skills based on MCQ test results}

Table 5 and 6 presents findings related to the evaluation of information literacy skills based on MCQ test results. Matrix of eight skills and four standards across Faculties are shown in Table 5. Scores are placed on a scale ranging from 0 to 1 . and SD range: 0.14 to 0.39 . Table 6 shows the level of each information literacy skill across Faculties. Scores are placed on a scale ranging from 0 to 1000 with standard error.

According to Table 6, highest mean scores were obtained for Skill4 - Using, finding tool features by undergraduates from Faculty of Architecture and Faculty of IT. Undergraduates from Faculty of Engineering across all the three Levels obtained the highest mean score for Skill5 - Retrieving sources. The lowest two mean scores were obtained for Skill 2 - Selecting and finding tools and Skill 8 - Understanding of economic, legal and social issues of information by undergraduates from all the three Faculties. This indicates undergraduates' difficulties irrespective of the discipline in identifying variety of types and formats of potential information sources as well as assessing economic, legal and social issues surrounding the use of information. 
Table 5 - Matrix of information literacy skills- Mean values

\begin{tabular}{|c|c|c|c|c|}
\hline Skill Standard & $\begin{array}{l}\text { Determine the } \\
\text { nature and extent } \\
\text { of information } \\
\text { needed }\end{array}$ & $\begin{array}{l}\text { Access required } \\
\text { information } \\
\text { effectively and } \\
\text { efficiently }\end{array}$ & $\begin{array}{l}\text { Evaluate } \\
\text { information and } \\
\text { its sources }\end{array}$ & $\begin{array}{l}\text { Understand many of the } \\
\text { economic, legal and } \\
\text { social issues }\end{array}$ \\
\hline $\begin{array}{l}\text { Developing a research } \\
\text { strategy (Skill1) }\end{array}$ & $\begin{array}{l}\text { Arch. L } 1= \\
0.31 \\
\text { IT L } 1=0.31 \\
\text { Eng. L } 1=0.32 \\
\text { Eng. L } 2=0.33 \\
\text { Eng. L } 4=0.33\end{array}$ & $\begin{array}{l}\text { Arch. L } 1=0.54 \\
\text { IT L } 1=0.48 \\
\text { Eng. L } 1=0.49 \\
\text { Eng. L } 2=0.51 \\
\text { Eng. L } 4=0.50\end{array}$ & & \\
\hline $\begin{array}{l}\text { Selecting and finding } \\
\text { tools } \\
\text { (Skill2) }\end{array}$ & $\begin{array}{l}\text { Arch. L } 1= \\
0.06 \\
\text { IT L } 1=0.18 \\
\text { Eng. L } 1=0.34 \\
\text { Eng. L } 2=0.26 \\
\text { Eng. L } 4=0.21\end{array}$ & $\begin{array}{l}\text { Arch. L } 1= \\
0.36 \\
\text { IT L } 1=0.27 \\
\text { Eng. L } 1=0.28 \\
\text { Eng. L } 2=0.29 \\
\text { Eng. L } 4=0.29\end{array}$ & $\begin{array}{l}\text { Arch. } L=0.17 \\
\text { IT L } 1=0.12 \\
\text { Eng. L } 1=0.18 \\
\text { Eng. L } 2=0.24 \\
\text { Eng. L } 4=0.28\end{array}$ & \\
\hline Searching (Skill3) & & $\begin{array}{l}\text { Arch. L } 1= \\
0.55 \\
\text { IT L } 1=0.33 \\
\text { Eng. L } 1=0.41 \\
\text { Eng. L } 2=0.56 \\
\text { Eng. L } 4=0.55\end{array}$ & & \\
\hline $\begin{array}{l}\text { Using finding tool } \\
\text { features (Skill4) }\end{array}$ & & $\begin{array}{l}\text { Arch. L } 1= \\
0.52 \\
\text { IT L } 1=0.49 \\
\text { Eng. L } 1=0.45 \\
\text { Eng. L } 2=0.58 \\
\text { Eng. L } 4=0.57\end{array}$ & & \\
\hline $\begin{array}{l}\text { Retrieving sources } \\
\text { (Skill5) }\end{array}$ & & $\begin{array}{l}\text { Arch. L } 1=0.42 \\
\text { IT L } 1=0.43 \\
\text { Eng. L } 1=0.53 \\
\text { Eng. L } 2=0.65 \\
\text { Eng. L } 4=0.64\end{array}$ & & \\
\hline $\begin{array}{l}\text { Evaluating sources } \\
\text { (Skill6) }\end{array}$ & & & $\begin{array}{l}\text { Arch. L } 1=0.41 \\
\text { IT L } 1=0.38 \\
\text { Eng. L } 1=0.32 \\
\text { Eng. L } 2=0.37 \\
\text { Eng. L } 4=0.57\end{array}$ & \\
\hline $\begin{array}{l}\text { Documenting sources } \\
\text { (Skill7) }\end{array}$ & & $\begin{array}{l}\text { Arch. L } 1= \\
0.52 \\
\text { IT L } 1=0.24 \\
\text { Eng. L } 1=0.31 \\
\text { Eng. L } 2=0.34 \\
\text { Eng. L } 4=0.39\end{array}$ & & $\begin{array}{l}\text { Arch. L } 1=0.43 \\
\text { IT L } 1=0.40 \\
\text { Eng. L } 1=0.41 \\
\text { Eng. L } 2=0.39 \\
\text { Eng. L } 4=0.47\end{array}$ \\
\hline $\begin{array}{l}\text { Understanding of } \\
\text { economic, legal and } \\
\text { social issues (Skill8) }\end{array}$ & & & & $\begin{array}{l}\text { Arch. L } 1=0.30 \\
\text { IT L } 1=0.25 \\
\text { Eng. L } 1=0.23 \\
\text { Eng. L } 2=0.27 \\
\text { Eng. L } 4=0.28\end{array}$ \\
\hline
\end{tabular}


However, it should be noted that information literacy is discipline specific (Catts, 2005). Therefore, direct comparisons across Faculties are not recommended.

Table 6 - Information literacy skills

\begin{tabular}{|c|c|c|c|c|c|}
\hline & \multicolumn{5}{|c|}{ Faculty } \\
\hline & \multirow{2}{*}{$\begin{array}{l}\text { Arch. } \\
\text { L } 1\end{array}$} & \multirow{2}{*}{$\begin{array}{l}\text { IT } \\
\text { L } 1\end{array}$} & \multicolumn{3}{|c|}{ Eng. } \\
\hline & & & L1 & L2 & L4 \\
\hline $\begin{array}{l}\text { Developing a research strategy } \\
\text { (Skill1) }\end{array}$ & $381 \pm 10$ & $370 \pm 26$ & $371 \pm 6$ & $388 \pm 9$ & $389 \pm 9$ \\
\hline $\begin{array}{l}\text { Selecting and finding tools } \\
\text { (Skill2) }\end{array}$ & $256 \pm 24$ & $250 \pm 39$ & $301 \pm 12$ & $279 \pm 22$ & $261 \pm 20$ \\
\hline Searching (Skill3) & $459 \pm 26$ & $281 \pm 54$ & $348 \pm 15$ & $457 \pm 21$ & $479 \pm 21$ \\
\hline $\begin{array}{l}\text { Using finding tool features } \\
\text { (Skill4) }\end{array}$ & $522 \pm 31$ & $490 \pm 52$ & $450 \pm 15$ & $582 \pm 20$ & $576 \pm 21$ \\
\hline Retrieving sources (Skill5) & $418 \pm 24$ & $434 \pm 47$ & $526 \pm 18$ & $653 \pm 24$ & $647 \pm 20$ \\
\hline Evaluating sources (Skill6) & $409 \pm 20$ & $375 \pm 39$ & $316 \pm 11$ & $368 \pm 20$ & $409 \pm 30$ \\
\hline Documenting sources (Skill7) & $461 \pm 19$ & $338 \pm 37$ & $379 \pm 11$ & $412 \pm 20$ & $448 \pm 19$ \\
\hline $\begin{array}{l}\text { Understanding of economic, } \\
\text { legal and social issues (Skill8) }\end{array}$ & $303 \pm 24$ & $250 \pm 61$ & $231 \pm 13$ & $265 \pm 20$ & $287 \pm 24$ \\
\hline
\end{tabular}

Table 7- Information literacy skills - foreign universities

\begin{tabular}{lcccc}
\hline Skill & $\begin{array}{c}\text { University } \\
\text { of } \\
\text { Connecticut } \\
\text { (USA) }\end{array}$ & $\begin{array}{c}\text { University } \\
\text { of Guelph } \\
\text { (Canada) }\end{array}$ & $\begin{array}{c}\text { Grand Valley } \\
\text { State } \\
\text { University } \\
\text { (USA) }\end{array}$ & $\begin{array}{c}\text { River Parishes } \\
\text { Community } \\
\text { College } \\
\text { (Italy) }\end{array}$ \\
\hline $\begin{array}{l}\text { Developing a research strategy } \\
\text { (Skill1) }\end{array}$ & $587 \pm 6$ & $591 \pm 14$ & $593 \pm 8$ & $532 \pm 17$ \\
$\begin{array}{l}\text { Selecting and finding tools } \\
\text { (Skill2) }\end{array}$ & $566 \pm 9$ & $573 \pm 20$ & $569 \pm 11$ & $514 \pm 24$ \\
$\begin{array}{l}\text { Searching (Skill3) } \\
\text { Using finding tool features }\end{array}$ & $645 \pm 10$ & $586 \pm 25$ & $641 \pm 16$ & $520 \pm 27$ \\
$\begin{array}{l}\text { (Skill4) } \\
\text { Retrieving sources (Skill5) }\end{array}$ & $580 \pm 11$ & $564 \pm 23$ & $596 \pm 16$ & $516 \pm 26$ \\
$\begin{array}{l}\text { Evaluating sources (Skill6) } \\
\text { Documenting sources (Skill7) }\end{array}$ & $595 \pm 6$ & $604 \pm 18$ & $610 \pm 9$ & $545 \pm 16$ \\
$\begin{array}{l}\text { Understanding of economic, } \\
\text { legal and social issues (Skill8) }\end{array}$ & $565 \pm 7$ & $616 \pm 21$ & $604 \pm 15$ & $499 \pm 20$ \\
\hline
\end{tabular}

Note: Scores are placed on a scale ranging from 0 to 1000 with standard error. Sources: University of Connecticut (2008), University of Guelph (2008), Grand Valley State University (2007), and River Parishes Community College (2008). 
The information literacy skills of undergraduates from some foreign universities are presented in Table 7. However, making direct comparisons between Table 6 and Table 7 is not recommended since there are differences in research instruments used by each university, structure of the questions, and number of questions used in assessing each skill.

\subsection{Overall score for information literacy skills}

Table 8 and Figure 1 show the overall mean score for information literacy skills across Faculties.

Table 8 - Information literacy skills- overall score

\begin{tabular}{lccccc}
\hline & \multicolumn{5}{c}{ Faculty } \\
\cline { 2 - 6 } & $\begin{array}{c}\text { Arch. } \\
\text { L 1 }\end{array}$ & IT 1 & L1 & L2 & L4 \\
\cline { 3 - 6 } & $\begin{array}{c}0.42 \\
\text { Overall mean score for }\end{array}$ & $\begin{array}{c}0.34, \\
(\mathrm{SD}=0.1 \\
\text { information literacy }\end{array}$ & $\begin{array}{c}0.36, \\
(\mathrm{SD}=0.13)\end{array}$ & $\begin{array}{c}0.43 \\
(\mathrm{SD}=0.11)\end{array}$ & $\begin{array}{c}0.43 \\
(\mathrm{SD}=0.14)\end{array}$ \\
\hline Note: Scores are placed on a scale ranging from 0 to 1. &
\end{tabular}

Note: Scores are placed on a scale ranging from 0 to 1.

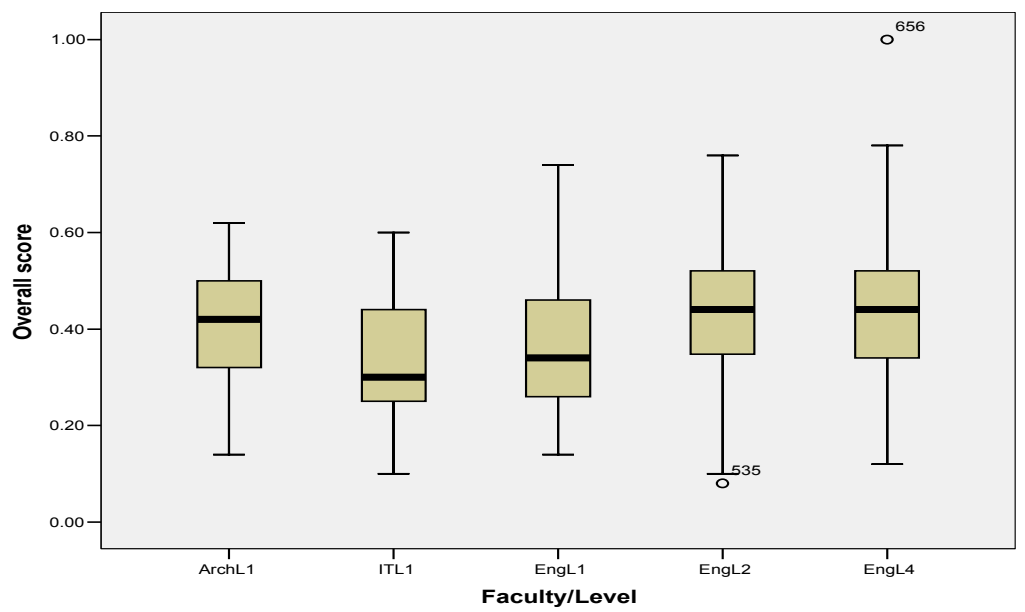

Figure 1- Information literacy - overall score

Figures 2 (a) to 2(e) show the distribution of overall scores across administrative districts from which undergraduates entered the university. 


\begin{tabular}{|c|c|c|c|c|c|}
\hline District & Code & District & Code & District & Sode \\
\hline$\overline{\text { Ampara }}$ & $\overline{1}$ & $\overline{\text { Jaffna }}$ & 9 & Matara & 17 \\
\hline Anuradhapura & 2 & Kalutara & 10 & Moneragala & 18 \\
\hline Badulla & 3 & Kandy & 11 & Mullativu & 19 \\
\hline Batticaloa & 4 & Kegalle & 12 & $\begin{array}{l}\text { Nuwara- } \\
\text { Eliya }\end{array}$ & 20 \\
\hline Colombo & 5 & Kilinochchi & 13 & Polonnaruwa & 21 \\
\hline Galle & 6 & Kurunegala & 14 & Puttalam & 22 \\
\hline Gampaha & 7 & Mannar & 15 & Ratnapura & 23 \\
\hline \multirow[t]{2}{*}{ Hambantota } & 8 & Matale & 16 & Trincomalee & 24 \\
\hline & & & & Vavunia & 25 \\
\hline
\end{tabular}

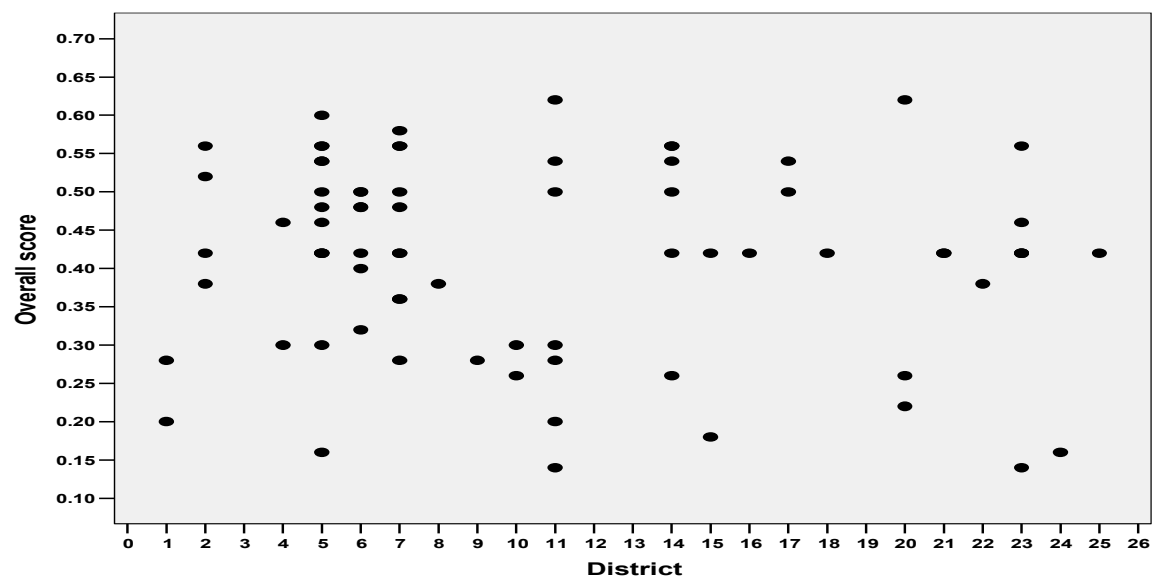

Figure - 2 (a): Arch. L 1

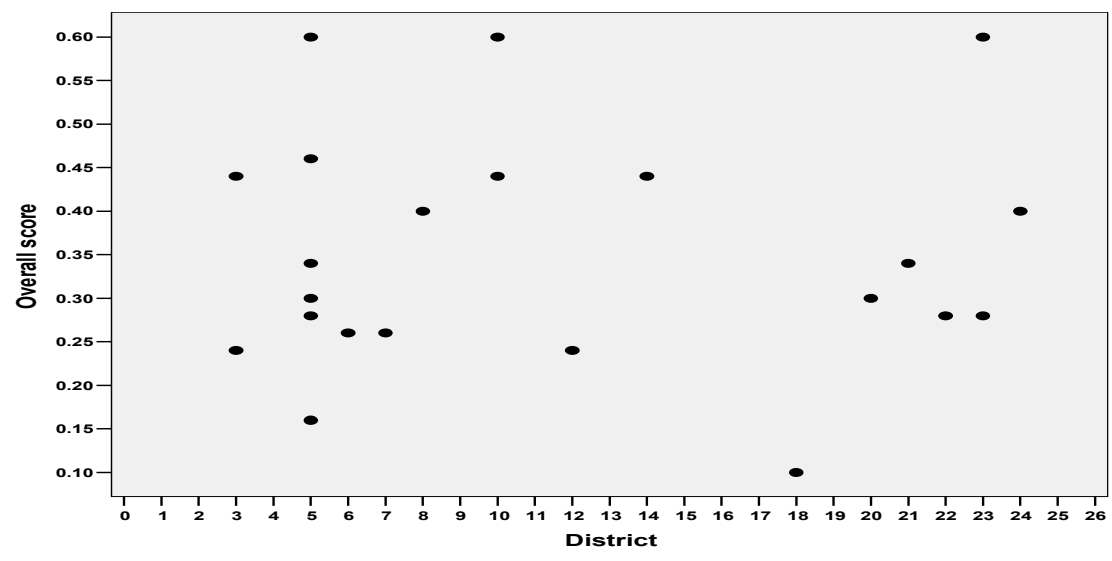

Figure - 2 (b): IT L 1 
Journal of the University Librarians Association of Sri Lanka. Vol.14 (Issue 1), June 2010

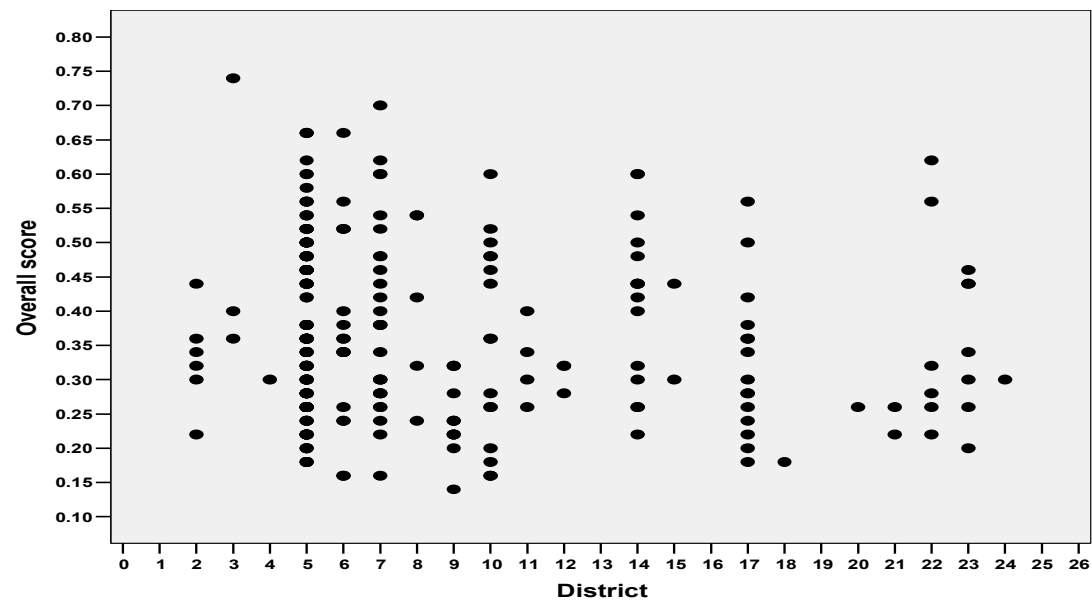

Figure - 2 (c): Eng. L 1

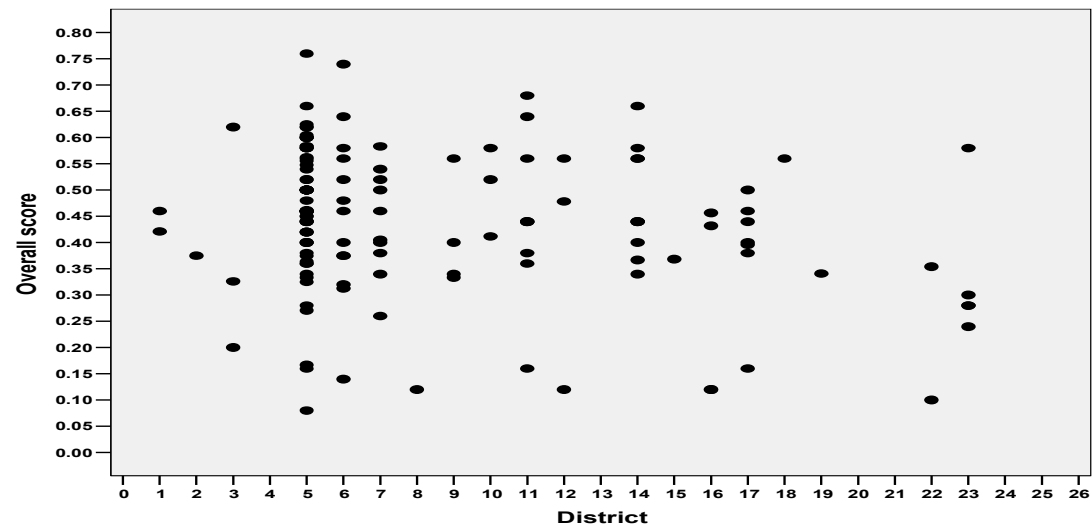

Figure - 2 (d): Eng. L 2

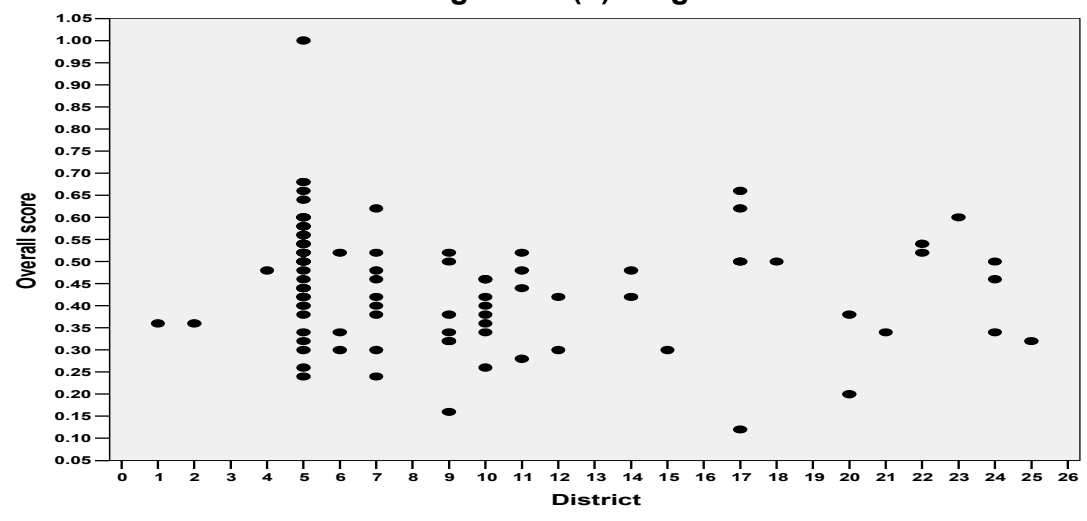

Figure - 2 (e): Eng. L 4

Note: Scores are placed on a scale ranging from 1 to 4. 


\subsection{Requirement of training to improve abilities in information literacy} skills

The study also inquired whether undergraduates perceive any requirement of training to improve their abilities in information literacy skills. The results are shown in Table 9.

Table 9 - Requirement of training to improve abilities in information literacy skills

\begin{tabular}{lcccccr}
\hline & \multicolumn{4}{c}{ Faculty } \\
\cline { 2 - 6 } & Arch. & IT & \multicolumn{3}{c}{ Eng. } \\
\cline { 5 - 7 } & L 1 & L 1 & L1 & L2 & L4 \\
\hline Training is not required (\%) & 42.0 & 23.0 & 40.0 & 40.0 & 24.0 \\
& & & & & 76. \\
Training is required (\%) & 58.0 & 77.0 & 60.0 & 60.0 & 0 \\
\hline
\end{tabular}

\subsection{Differences in information literacy skills by demographic characteristics of undergraduates}

Data was analyzed to identify whether statistically significant differences exist in information literacy skills of undergraduates across demographic characteristics, namely, $Z$ Score in the A/L examination, age, gender, ethnicity, religion, whether their mother is in a paid employment or housewife, and whether they had relatives living with them (such as grandparents) (Refer to Table 3). However, statistically significant differences have not been found either in information literacy test results, or perceived levels of information literacy skills. This confirms Thirion and Pochet's (2009) observation, that individual characteristics and family background of undergraduates do not show statistically significant effects.

\section{Concluding remarks}

The study investigated information literacy skills of undergraduates and found the necessity of assessing information literacy skills of undergraduates across undergraduate degree programmes. To improve the level of information literacy skills of undergraduates, universities across the world, to date, use two main strategies.

First is to create a separate "information literacy skills course" (Fallows and Steven, 2000). For instance LOEX Clearinghouse (n.d) and Wang (2006) 
provide evidence for broader use of courses on information literacy to enhance the skill levels of undergraduates. Further, Wang (2006) found statistically significant differences in "citation use" and "academic grades" between undergraduates who took "credit courses" on information literacy and those who did not take credit courses, in the USA. However, none of the universities in Sri Lanka has taken information literacy into the undergraduate curriculum to date (Ranaweera, 2009).

Second is to place "information literacy skills" on the same level as "subject skills", thereby communicating the message that these are important to be learnt. In this regard, some scholars suggest (e.g. Marcum, 2002; Orr and Cribb, 2003) that information literacy skills should be included as part of course curricula within each discipline, rather than stand-alone sessions run by the library. The emphasis is on librarians to collaborate with academic colleagues and put more time into liaison, and course development and teaching (Marcum, 2002; Orr and Cribb, 2003). For instance, Emmett and Emde (2006) report a marked improvement in undergraduate information literacy skills when these are taught jointly by academic lecturers and librarians. In this regard, Thirion and Pochet (2009) state, "training should be planned as a partnership between the teacher and the librarian, so that both can bring in their specific knowledge. Generally the teacher alone does not have a complete mastery of the advanced specificities of information tools and techniques. And the librarian alone also cannot help the students with the core competences required for specific topics. However, the relevance of combining both has already been proved" (2009, p. 169). However, exactly where in the curriculum these skills should be included is largely a local decision (see Zinser, 2003).

It should be, however, noted that formulating strategies to improve information literacy skills at the University of Moratuwa is beyond the scope of this study.

\section{Acknowledgement}

First, the authors would like to acknowledge the Senate Research Committee of University of Moratuwa for providing financial assistance for this research. 
Second, the authors appreciate the efforts of academic staff who helped in data collection.

\section{References}

American Library Association. (1989). Final report from the presidential committee on information literacy, Washington, DC

Association of College and Research Libraries (ACRL).( 2000). Information literacy competency standards for higher education. Retrieved on November 10, 2008 from http://www.acrl.org/ala/mgrps/divs/acrl/standards/ standards.pdf

Camuffo, A., and Gerli, F. (2004). An integrated competency based approach to management education: an Italian MBA case study. International Journal of Training and Development, 8(4), 240-257.

Catts, R. (2005). Information skills survey-technical manual. Canberra: CAUL.

Catts, R. and Lau, J. (2008). Towards information literacy indicators. UNESCO.

Council of Australian University Librarians. (2001). Information literacy standards. Canberra: CAUL.

Emmett, A. and Emde, J. (2006). Assessing information literacy skills using the ACRL standards as a guide. Reference Services Review, 35(2), 210229.

Fallows, S. and Steven, C.(2000). Building employability skills into the higher education curriculum: a university-wide initiative. Education + Training, 42(2), 75-82.

Graham, M.E., and Tarbell, L.M. (2006). The importance of the employee perspective in the competency development of human resource professionals. Human Resource Management, 45( 3), 337-355.

Grand Valley State University (2007). Results of the standardized assessment of information literacy skills for Grand Valley State University, Retrieved on October 12, 2009 from http://main.gvsu.edu/cms3/assets/ 741ECAAEBD54-A816-1DAF591D1D7955C/ assessment/Results2007.pdf

Jayatissa, L.A. (2009). A multi-faceted programme for information skills development: University of Kelaniya. Journal of the University Librarians Association of Sri Lanka, 13(Special Issue), 5-22. 
LOEX Clearinghouse (a non-profit educational clearinghouse for library instruction and information literacy information) (n.d). Available at http://www.emich.edu/public/loex/loex.html

Marcum, J.W.(2002). Rethinking information literacy. Library Quarterly, 72(1), 1-26.

Marsh, H. (1984). Students' evaluations of university teaching: dimensionality, reliability, validity, potentials biases, and utility. Journal of Educational Psychology 76, 707-727.

Orr, D., and Cribb, J. (2003). Information literacy: is it worth the investment? Australian Academic and Research Libraries, 34(1), 42-51.

Project SAILS (2009). Project SAILS Skill Sets for the 2009-2010 Academic Year, Retrieved on January 20, 2009 from https://www.projectsails.org/abouttest/skillsets.php?page=aboutTest

Ranaweera, P. A. (2009). Information Literacy Programmes in Higher Education Sector in Sri Lanka. Paper presented at the NILIS Research Symposium, Colombo, Sri Lanka, 20-21 March.

River Parishes Community College (2008). Results of the standardized assessment of information literacy skills for River parishes Community College. Retrieved on October 12, 2009 from http://www.rpcc.edu/uploads/ SAILS Fall2008 RPCC NoQuestions.pdf

Thirion, P. and Pochet, B. (2009), Information literacy in students entering higher education in the French Speaking Community of Belgium: lessons learned from an evaluation. Official Journal of the International Federation of Library Associations and Institutions, 35(2), 89-208.

University of Connecticut. (2007). Results of the standardized assessment of information literacy skills. Retrieved on December 5, 2009 from http://assessment.uconn.edu/docs/GenEd/UConn SAILS Fall 2007 Administration.pdf.

University of Guelph (2008). Results of the standardized assessment of information literacy skills for Guelph, University of Guelph. Retrieved on October 12, 2009 from http://www.lib.uoguelph.ca/ services/information literacy \& instruction/information literacy testing/components/documents ISAILS UG results 2008.pdf

Wang, R. 2006. The lasting impact of a library credit course. Portal : Libraries and the Academy, 6(1), 79-82.

Zinser, R. (2003). Developing career and employability skills: a US case study. Education + Training, 45(7), 402-410. 